\title{
Interleukin 12 receptor deficiency in a child with recurrent bronchopneumonia and very high $\operatorname{lgE}$ levels
}

\author{
Loredana Palamaro ${ }^{1}$, Giuliana Giardino ${ }^{1}$, Francesca Santamaria ${ }^{1}$, Rosa Romano ${ }^{1}$, Anna Fusco ${ }^{1}$, Silvia Montella ${ }^{1}$, \\ Mariacarolina Salerno ${ }^{1}$, Matilde Valeria Ursini ${ }^{2}$ and Claudio Pignata ${ }^{1,3^{*}}$
}

\begin{abstract}
Interleukin-12 (IL-12) is involved in cellular immune responses against intracellular pathogens by promoting the generation of T naive in T helper 1 (Th1) cells and by increasing interferon-gamma (IFN-gamma) production from T and natural killer (NK) cells. A defective induction of a Th1 response may lead to a higher risk of infections, and, in particular, infections due to typical and atypical Mycobacteria. We report on the case of a girl with suffering from recurrent bronchopneumonia associated with very high serum IgE levels, who exhibited a profound impairment of the Th1 generation associated with a novel mutation in the exon 5 of the IL-12R $\beta 1$ gene (R156H). Our data suggest that in children with severe and recurrent infections, even in the absence of a mycobacterial infection, functional and/or genetic alterations of the molecular mechanisms governing Th1/Th2 homeostasis might be responsible for an atypical immunodeficiency and, therefore, should be investigated in these patients.
\end{abstract}

Keywords: Immunodeficiency, IL-12/IL-12 receptor, Recurrent pneumonia

\section{Background}

Primary congenital immunodeficiencies encompass a wide spectrum of distinct clinical entities, which differ in either pathogenetic mechanism or clinical features. Recently, several novel syndromes with unusual phenotypes have been described [1,2]. However, in a number of patients suffering from severe and sometimes life-threatening infections, in which an immunological disorder is suspected, the underlying genetic defect responsible for the immunodeficiency still remains to be elucidated [3]. Recently, a higher susceptibility to intracellular pathogens and, in particular, atypical mycobacterial and salmonella infections has been described in patients with genetic alterations of the IL-12 receptor (IL-12R) [4-9]. IL-12 stimulates cellular immune responses against intracellular pathogens by promoting the generation of $\mathrm{T}$ naive in $\mathrm{T}$ helper 1 (Th1) cells and by increasing interferon-gamma (IFN-gamma) production

\footnotetext{
* Correspondence: pignata@unina.it

'Department of Pediatrics, "Federico II" University, Naples, Italy

${ }^{3}$ Unit of Immunology, Department of Pediatrics, "Federico II" University, Via S. Pansini 5-80131, Naples 80127, Italy

Full list of author information is available at the end of the article
}

from $\mathrm{T}$ and natural killer (NK) cells. Induction of a Th1 response and cell cycle progression mostly relies on the expression of a high affinity IL-12R, consisting of $\beta 1$ and $\beta 2$ chains [10-15]. A few genetic alterations of $\beta 1$ chain have already been reported in patients suffering of mycobacterial infections [5,6].

\section{Case presentation}

A 8-year-old girl was referred to the our Department because of a history of recurrent pneumonia (4 episodes over 2 years). At the age of 4 years and 8 months she had suffered from the first episode of middle lobar bronchopneumonia requiring hospitalization. In that occasion the total IgE serum levels were $3350 \mathrm{kU} / \mathrm{l}$. One month later, she was hospitalized for a second bronchopneumonia episode interesting both lungs followed by persistent cough for more than a month. These episodes were responsive to antibiotic therapy. Subsequently, she had suffered from 2 additional bronchopneumonia episodes in distinct lung area, successfully treated with parenteral antibiotic therapy. Conventional $\mathrm{x}$-ray and high resolution computed tomography of the chest revealed multiple focal consolidations in both lungs, confirmed 
by magnetic resonance imaging [16]. Acid resistant bacillus was not found in the sputum examination. In one occasion, Haemophilus influenzae was isolated on sputum culture. Weight and height growth was in the normal range. No infections in other organs were reported. The routine immunological evaluation revealed normal IgG and IgA, but very high serum IgE levels (> $2000 \mathrm{kU} / \mathrm{l}$ ), confirmed in several occasions during the 2 years follow-up. Specific IgE toward Dermatophagoides farinae and pteronyss, olive, herb vitriol and Parietaria judaica were detected. Prick test were positive (ponf $>0.3 \times 0.4 \mathrm{~cm}$ ) for Dermatophagoides farinae and pteronyss, hair of dog, Parietaria and olive, thus confirming a multiple sensitivity. The patient showed a proper antibody specific response as demonstrated by the presence of IgG antibody serum levels, tested by immuno-enzymatic method, against B-hepatitis, parotitis and German measles viruses. Serum IgG, IgA e IgM levels were always in the normal range. The immunophenotype valuation revealed normal number and percentage of the lymphocyte subpopulations studied (Table 1).

The patient's family history was notable for the presence of allergic disorders in both lineages. In particular, her mother and grandmother had a history of allergic rhinitis, while her father had urticaria. A maternal aunt died at 2 years of age by whooping-cough and a maternal uncle died at 16 months by a severe not better specified respiratory infection. A paternal aunt and her daughter had a history of allergic rhinitis.

We first determined the proliferative response of PBMC to CD3 cross-linking, that mimics in vivo antigen exposure, performed at optimal $(1 \mathrm{ng} / \mathrm{ml})$ or suboptimal

Table 1 Immunonological parameters

\begin{tabular}{lcc}
\hline Lymphocyte subpopulations & \% & $\mathbf{n} / \mathbf{m m}^{\mathbf{3}}$ \\
\hline CD3 & 77 & 2.956 \\
\hline CD3DR & 4.2 & 161.28 \\
\hline CD8 & 39.3 & 1509 \\
\hline CD19 & 30.2 & 1159 \\
\hline CD56 & 11.4 & 437.76 \\
\hline CD4-CD8-TCR a/ + & 3.4 & 130.56 \\
\hline CD4-CD8-TCR g/d+ & 2.3 & 88.32 \\
\hline Specific antibody responses & 2.2 & 84.48 \\
\hline B-hepatitis virus & IgG & IgM \\
\hline Parotidis virus & Present & Absent \\
\hline German measles virus & Present & Absent \\
\hline Proliferative response to & Patient & Absent \\
\hline mitogens stimulation & (mean \pm SE) & Control \\
\hline PMA + iono & 22458 \pm 11013 & $32159 \pm 27858$ \\
\hline CD3 X-L & $800 \pm 68$ & $29500 \pm 3000$ \\
\hline
\end{tabular}

(0.3 ng/ml) antibody concentration. The proliferation at the maximal dosage was significantly lower in the patient than in the controls (mean \pm SE were: $800 \pm 68 \mathrm{cpm}$ and $29500 \pm 3000 \mathrm{cpm}$ in the proband and controls, respectively). Since a proper immune response to pathogens requires a Th1 induction and this process determines up-regulation of the expression of the IL-12R $\beta 2$ chain, we evaluated mRNA expression of this molecule after mitogen stimulation of PBMC in vitro. No expression of IL-12R $\beta 2$ transcript was found in patient's cells (Figure 1A), differently from the controls. IL-12R $\beta 1$ was expressed at normal levels (Figure 1B).

At molecular level, gene sequencing of IL-12R $\beta 2$ gene revealed a missense mutation ( $\mathrm{G}$ to $\mathrm{A}$ ) at nucleotide 531 in the exon 5 in heterozygosity, resulting in the substitution of arginine (CGT) with histidine (CAT) in the extracellular domain of the receptor at the same aminoacid position 156 (designed R156H) (Figure 2). The mutation was not a polymorphism since was not found in 100 chromosomes from unrelated individuals. This $\mathrm{G}$ to $\mathrm{A}$ transition creates a new restriction site for NdeI enzyme (data not shown).

\section{Discussion}

The case here reported indicates that alterations of the induction of a proper Th1 response may be associated with an atypical immunodeficiency characterized by high susceptibility to infections. The functional response of lymphocytes to IL-12 depends on the expression of a high affinity IL-12 receptor on Th1 and NK cells. The high affinity receptor for IL-12 consists of two subunits,

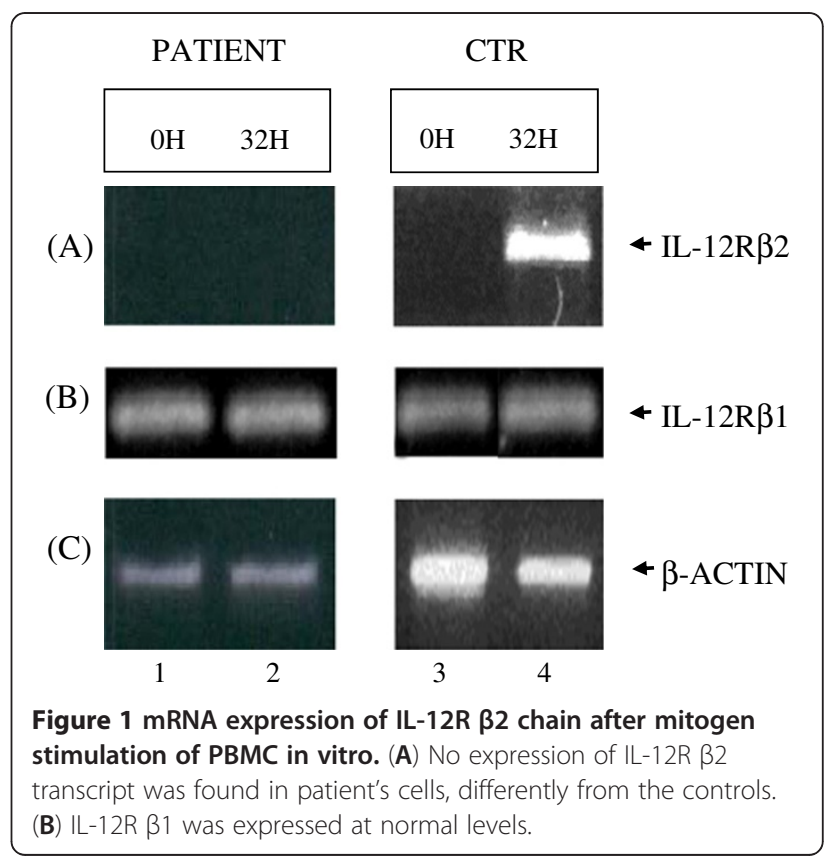




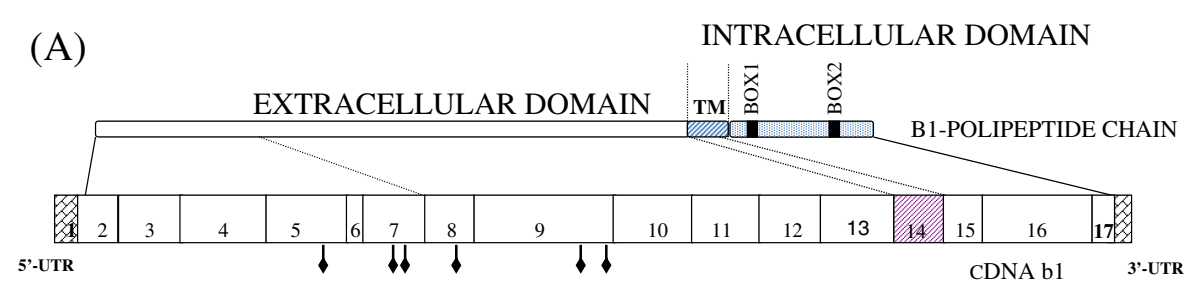

DESCRIBED MUTATION SITES

(B)

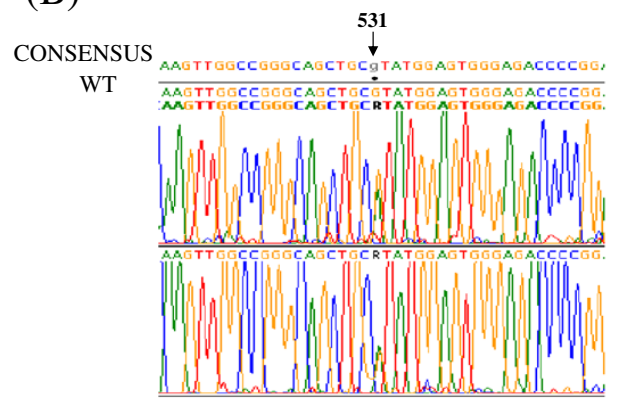

PATIENT

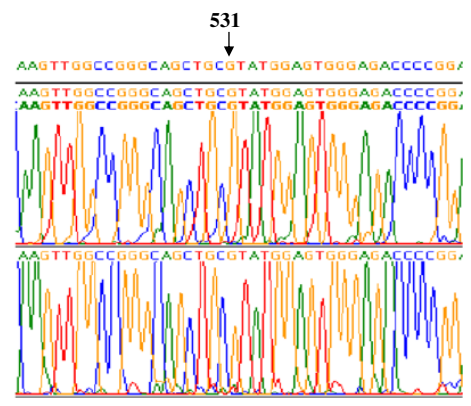

CTR

Figure 2 gene sequencing of IL-12R $\beta 2$ gene. At molecular level, gene sequencing of IL-12R $\beta 2$ gene revealed a missense mutation (G to A) at nucleotide 531 in the exon 5 in heterozygosity, resulting in the substitution of arginine (CGT) with histidine (CAT) in the extracellular domain of the receptor at the same aminoacid position 156 (designed R156H).

$\beta 1$ and $\beta 2$, closely related to the cytokine receptor glycoprotein (gp) 130 [11,17]. The complete IL-12R is thought to be associated with the development, being expressed on human naive $\mathrm{T}$ cells during differentiation to Th1 but not to Th2. Therefore, the expression of these molecules is generally considered as a marker of Th1 dominated response [11-13,16]. Th1 cells produce IFN-gamma and IL-2 and, predominantly, promote cell mediate immune responses against intracellular pathogens $[18,19]$. In a previous study, we provided evidence of altered IL-12/IL-12R signaling in patients with very high IgE levels, suggestive of an impaired Th1 induction [20]. A defective induction of a Th1 response in patients may lead to a higher risk of infections, thus worsening the overall outcome of patients with very high IgE levels. In the case herein described a genetic alteration of the IL-12R $\beta 1$ has been found in heterozygosity. Whether this alteration is really responsible for the phenotype remains to be definitively demonstrated with further molecular and functional studies. However, it should be noted that patients with homozygous alterations of the same gene have already been reported, being affected with a more severe clinical phenotype and selective susceptibility to mycobacterial infections [5,6]. Based on this clinical observation, we suggest that a better understanding of the molecular mechanisms governing Th1/ Th2 homeostasis may help recognize novel clinical phenotypes of atypical immunodeficiencies.

\section{Consent}

Written informed consent was obtained from the parents of the patient for publication of this Case report and any accompanying images.

\section{Abbreviations}

IL-12: Interleukin-12; Th1: T helper 1; IFN-gamma: Interferon-gamma; NK: Natural Killer.

\section{Competing interests}

The authors declare that they have no competing interests.

\section{Authors' contributions}

LP has made substantial contributions to conception and design, has been involved in drafting the manuscript, and has given final approval of the version to be published. GG has made substantial contributions to conception and design, has been involved in drafting the manuscript, and has given final approval of the version to be published. FS has made substantial contributions to conception and design, has been involved in revising the manuscript critically for important intellectual content, and has given final approval of the version to be published. RR and AF has made substantial contributions to acquisition of data, has been involved in drafting the manuscript, and has given final approval of the version to be published. SM has made substantial contributions to acquisition of data, has been involved in revising the manuscript critically for important intellectual content, and has given final approval of the version to be published. MVU has made substantial contributions to conception and design and analysis and interpretation of data, has been involved in revising the manuscript critically for important intellectual content, and has given final approval of the version to be published. CP has made substantial contributions to conception and design and analysis and interpretation of data, has been involved in drafting the manuscript and revising it critically for important intellectual content, and has given final approval of the version to be published. 


\section{Author details}

${ }^{1}$ Department of Pediatrics, "Federico II" University, Naples, Italy. ${ }^{2}$ International Institute of Genetics and Biophysics, CNR, Naples, Italy. ${ }^{3}$ Unit of Immunology, Department of Pediatrics, "Federico II" University, Via S. Pansini 5-80131, Naples 80127, Italy.

Received: 1 September 2012 Accepted: 14 September 2012 Published: 19 September 2012

\section{References}

1. Palamaro L, Vigliano I, Giardino G, Cirillo E, Aloj G, Romano R, Pignata C: SCID-like phenotype associated with an inhibitory autoreactive immunoglobulin. J Investig Allergol Clin Immunol 2012, 22:67-70.

2. De Vries E, Alvarez Cardona A, Abdul Latiff AH, Badolato R, Brodszki N, Cant AJ, Carbone J, Casper JT, Ciznar P, Cochino AV, Conley ME, Derfalvi B, Driessen GJ, Elfeky R, Espanol T, Glimour K, Gueseva MN, Haverkamp MH, Helminen M, Honig M, Kanariou MG, Kirschfink M, Klein C, Kuijpers TW, Kutukculer N, Martire B, Meyts I, Niehues T, Pignata C, Reda SM, Renner ED, Rezaei N, Rizzi M, Sampalo Lainz MA, Sargur RB, Sediva A, Seidel MG, Seneviratne SL, Soler-Palacin P, Tommasini A, Warnatz K: Patient-centred screening for primary immunodeficiency, a multi-stage diagnostic protocol designed for non-immunologists: 2011 update. Clin Exp Immunol 2012, 167:108-119.

3. Aloj G, Giardino G, Valentino L, Maio F, Gallo V, Esposito T, Naddei R, Cirillo E, Pignata C: Severe combined immunodeficiences: new and old scenarios. Int Rev Immunol 2012, 31:43-65.

4. Aytekin C, Dogu F, Tuygun N, Tanir G, Guloglu D, Boisson-Dupuis S, Bustamante J, Feinberg J, Casanova JL, Ikinciogullari A: Bacille CalmetteGuèrin lymphadenitis and recurrent oral candidiasis in an infant with a new mutation leading to interleukin-12 receptor beta-1 deficiency. $J$ Invest Allergol Clin Immunol 2011, 21:401-404.

5. Pedraza-Sanchez S, Herrera-Barrios MT, Aldana-Vergara R, Neumann-Ordoez M, Gonzalez-Hernandez Y, Sada-Dìaz E, de Beaucoudrey L, Casanova JL, Torres-Rojas M: Bacille Calmette-Guèrin infection and disease with fatal outcome associated with a point mutation in the interleukin-12/ interleukin-23 receptor beta-1 chain in two Mexican families. Int J Infect Dis 2010, 14:e256-e260.

6. Shah P, El-Maaytah M, Jerjes W, Upile T, Ayliffe P: Interleukin 12 receptor beta1 chain deficiency in a child with disseminated tuberculosis: a case report. J Oral Maxillofac Surg 2010, 68:909-911.

7. Granados EL, Porpiglia AS, Hogan MB, Matamoros N, Krasovec S, Pignata C, Smith CIE, Hammarstrom L, Bjorkander J, Belohradsky BH, Fontan Casariego G, Garcia Rodriguez MC, Conley ME: Clinical and molecular analysis of patients with defects in micro heavy chain gene. J Clin Invest 2002, 110:1029-1035.

8. Altare F, Durandy A, Lammas D, Emile JF, Lamhamedi S, Le Deist F, Drysdale P, Jouanguy E, Doffinger R, Bernaudin F, Jeppsson O, Gollob JA, Meinl E, Segal AW, Fischer A, Kumararatne D, Casanova JL: Impairment of mycobacterial immunity in human interleukin-12 receptor deficiency. Science 1998, 280:1432-1435.

9. Sakai T, Matsuoka M, Aoki M, Nosaka K, Mitsuya H: Missense mutation of the interleukin-12 receptor beta1 chain-encoding gene is associated with impaired immunity against Mycobacterium avium complex infection. Blood 2001, 97:2688-2694.

10. Presky DH, Yang H, Minetti $\amalg$, Chua AO, Nabavi N, Wu CY, Gately MK Gubler U: A functional interleukin 12 receptor complex is composed of two $\beta$-type cytokine receptor subunits. Proc Natl Acad Sci USA 1996, 93:14002-14007.

11. Rogge L, Barberis-Maino L, Biffi M, Passini N, Presky DH, Gubler U, Sinigaglia F: Selective expression of an interleukin-12 receptor component by human T helper 1 cells. J Exp Med 1997, 185:825-831

12. Szabo SJ, Dighe AS, Gubler U, Murphy KM: Regulation of the interleukin (IL) -12RB2 subunit expression in developing T helper 1 (Th1) and Th2 cells. J Exp Med 1997, 185:817-824.

13. Gately MK, Renzetti LM, Magram J, Stern AS, Adorini L, Gubler U, Presky DH: The interleukin-12/interleukin-12-receptor system: role in normal and pathologic immune responses. Annu Rev Immunol 1998, 16:495-521.

14. Amorosi S, Russo I, Amodio G, Garbi C, Vitiello L, Palamaro L, Adriani M, Vigliano I, Pignata C: The cellular amount of the common $\gamma$-chain influences spontaneous or induced cell proliferation. J Immunol 2009, 182:3304-3309.
15. Vigliano I, Palamaro L, Bianchino G, Fusco A, Vitiello L, Grieco V, Romano R, Salvatore M, Pignata C: Role of the common g chain in cell cycle progression of human malignant cell lines. Int Immunol 2012, 24:159-167.

16. Montella S, Maglione M, Bruzzese D, Mollica C, Pignata C, Aloj G, Manna A, Esposito A, Mirra V, Santamaria F: Magnetic resonance imaging is an accurate and reliable method to evaluate non-cystic fibrosis paediatric lung disease. Respirology 2012, 17:87-91.

17. Presky DH, Minetti LJ, Gillessen S, Wilkinson VL, Wu CY, Gubler U, Chizzonite R, Gately MK: Analysis of the multiple interactions between IL-12 and the high affinity IL-12 receptor complex. J Immunol 1998, $160: 2174-2179$

18. Santoni $D$, Pedicini $M$, Castiglione F: Implementation of a regulatory gene network to simulate the $\mathrm{TH} 1 / 2$ differentiation in an agent-based model of hypersensitivity reactions. Bioinformatics 2008, 24:1374-1380.

19. Finkelman FD, Vercelli D: Advances in asthma, allergy mechanisms, and genetics in 2006. J Allergy Clin Immunol 2007, 120:544-550.

20. Fusco A, Vigliano I, Palamaro L, Cirillo E, Aloj G, Piscopo G, Giardino G, Pignata C: Altered signaling through IL-12 receptor in children with very high serum IgE levels. Cell Immunol 2010, 265:74-79.

doi:10.1186/1824-7288-38-46

Cite this article as: Palamaro et al:: Interleukin 12 receptor deficiency in a child with recurrent bronchopneumonia and very high IgE levels. Italian Journal of Pediatrics 2012 38:46.

\section{Submit your next manuscript to BioMed Central and take full advantage of:}

- Convenient online submission

- Thorough peer review

- No space constraints or color figure charges

- Immediate publication on acceptance

- Inclusion in PubMed, CAS, Scopus and Google Scholar

- Research which is freely available for redistribution 